\title{
PELATIHAN MITIGASI BENCANA DALAM MENGHADAPI PANDEMI COVID-19 DI DUSUN KALEBAJENG KELURAHAN KALEBAJENG KECAMATAN BAJENG KABUPATEN GOWA
}

\author{
Ayu Puspitasari ${ }^{1}$, Harpiana Rahman ${ }^{2}$ \\ ${ }^{1,2)}$ Program Studi Kesehatan Masyarakat, Fakultas Kesehatan Masyarakat, Universitas Muslim Indonesia \\ e-mail: ayupuspitasari@umi.ac.id
}

\begin{abstract}
Abstrak
Darurat wabah virus Corona sedang dihadapi dunia saat ini. WHO (World Health Organization) telah mengubah statusnya dari Public Health of International Concern menjadi Pandemi. Dengan ditetapkannya status tersebut dunia pun responsif dengan upaya pencegahan dan penanggulangan tidak terkecuali di Indonesia. Oleh karena itu perlu adanya pemahaman tentang mitigasi bencana pandemi Covid-19. Langkah-langkah dalam penanganan wabah perlu diketahui secara luas oleh masyarakat agar dapat mengambil langkah preventif dalam menghadapi wabah Covid-19. Pelatihan mitigasi bencana pandemic Covid-19 dimulai dari langkah-langkah Pencegahan dan pengendalian Infeksi, Pencegahan dan Pengendalian Infeksi untuk Isolasi di Rumah (Perawatan di Rumah), Pencegahan dan Pengendalian Infeksi untuk Observasi, Pencegahan dan Pengendalian Infeksi untuk Pemulangan Jenazah. Berdasarkan hasil pre dan post test pada 52 orang yang terdiri dari 10 pertanyaan kuesioner, terdapat peningkatan pengetahuan mengenai mitigasi bencana Covid-19. Berdasarkan persentasi hasil yang dicapai, diketahui bahwa terdapat peningkatan pengetahuan masyarakat sebesar $36,2 \%$ setelah mengikuti pelatihan ini. Pentingnya sosialisasi dari pemerintah setempat mengenai mitigasi bencana covid secara berkelanjutan selama pandemi berlangsung.
\end{abstract}

Kata kunci: Covid-19, Mitigasi, Bencana

\begin{abstract}
The world is facing the emergency of the Corona virus outbreak right now. WHO (World Health Organization) has also changed its status from Public Health of International Concern to Pandemic. With the stipulation of this status, the world is also responsive to prevention and overcoming efforts, including in Indonesia. Therefore it is necessary to have an understanding of the Covid-19 pandemic disaster mitigation. The public needs to know about the steps in handling the outbreak so that they can take preventive steps in dealing with the Covid-19 outbreak. Covid-19 pandemic disaster mitigation training starts from steps to Prevent and control Infections, Infection Prevention and Control for Isolation at Home (Home Care), Infection Prevention and Control for Observation, Prevention and Infection Control for the Return of the Body. Based on the results of the pre and post test on 52 people consisting of 10 questionnaire questions, there is an increase in knowledge about covid-19 disaster mitigation. Based on the percentage of results achieved, it is known that there is an increase in people's knowledge by $36.2 \%$ after participating in this training. The importance of socialization from the local government regarding the sustainable mitigation of the Covid disaster during the pandemic.
\end{abstract}

Keywords: Covid-19, Mitigation, Disaster

\section{PENDAHULUAN}

Bencana adalah sebuah gangguan serius di dalam fungsi komunitas atau masyarakat yang mengakibatkan kerugian materi, ekonomi, social, atau lingkungan yang melebihi kemampuan masyarkat untukmengatasinya (Central Board Of Secondary Education, 2006).

Memaknai bencana lebih lanjut pada UU No. 24/2007 tentang Penanggulangan Bencana mengartikan bencana sebagi peristiwa atau rangkaian peristiwa yang mengancam dan mengganggu kehidupan dan penghidupan masyarakat yang disebabkan oleh faktor alam dan/ atau faktor non alam maupun faktor manusia sehingga mengakibatkan timbulnya korban jiwa manusia, kerusakan lingkungan, kerugian harta benda, dan dampak psikologis. 
Menurut data dari Worldmeters (2020), saat ini Indonesia memiliki 686 total kasus, dengan jumlah kasus baru sebanyak 107 orang dengan angka kematian sebanyak 55 orang yang nilainya cukup tinggi di banding pendahulunya seperti Singapura dan Saudi Arabia dengan masing-masing total kasus sebanyak 509 dan 562 dengan angka kematian 2 dan 0.

Demi mencegah meluasnya penyebaran virus corona, inisiatif tanggap darurat dan usaha preventif pun dilaksanakan. Bencana tidak mungkin bisa ditolak, tetapi segenap kemampuan untuk pencegahan dan perlindungan menjadi hal yang sangat mungkin dilakukan. Dengan rencana mitigasi, korban bencana yang lebih besar bisa dihindari. Meski langkah yang diambil cukup terlambat tetapi langkah mitigasi bencana harusnya tepat sasaran.

Pendidikan kesehatan tentang Mencegah Penularan Virus Corona Penyebab Covid-19 diberikan kepada orang tua murid kelas IV MIN 3 Padamg yang tergabung dalam group Whatsapp orang tua. Kegiatan ini dilaksanakan pada tanggal 10 April 2020 yang dimulai pada jam 10.00 11.00 WIB, yang diikuti oleh 40 orang, dengan rincian rentang usia 25-40 tahun. Hasil yang diperoleh terdapat $68 \%$ peserta yang bertanya tentang materi dan terdapat $80 \%$ peserta yang telah memahami materi pendidikan kesehatan yang diberikan (Etri dkk, 2020).

Tujuan pelaksanaan pengabdian masyarakat di Dusun Kalebajeng adalah untuk meningkatkan pengetahuan masyarakat mengenai mitigasi bencana Covid-19 ditengah pandemi yang tengah berlangsung ini.

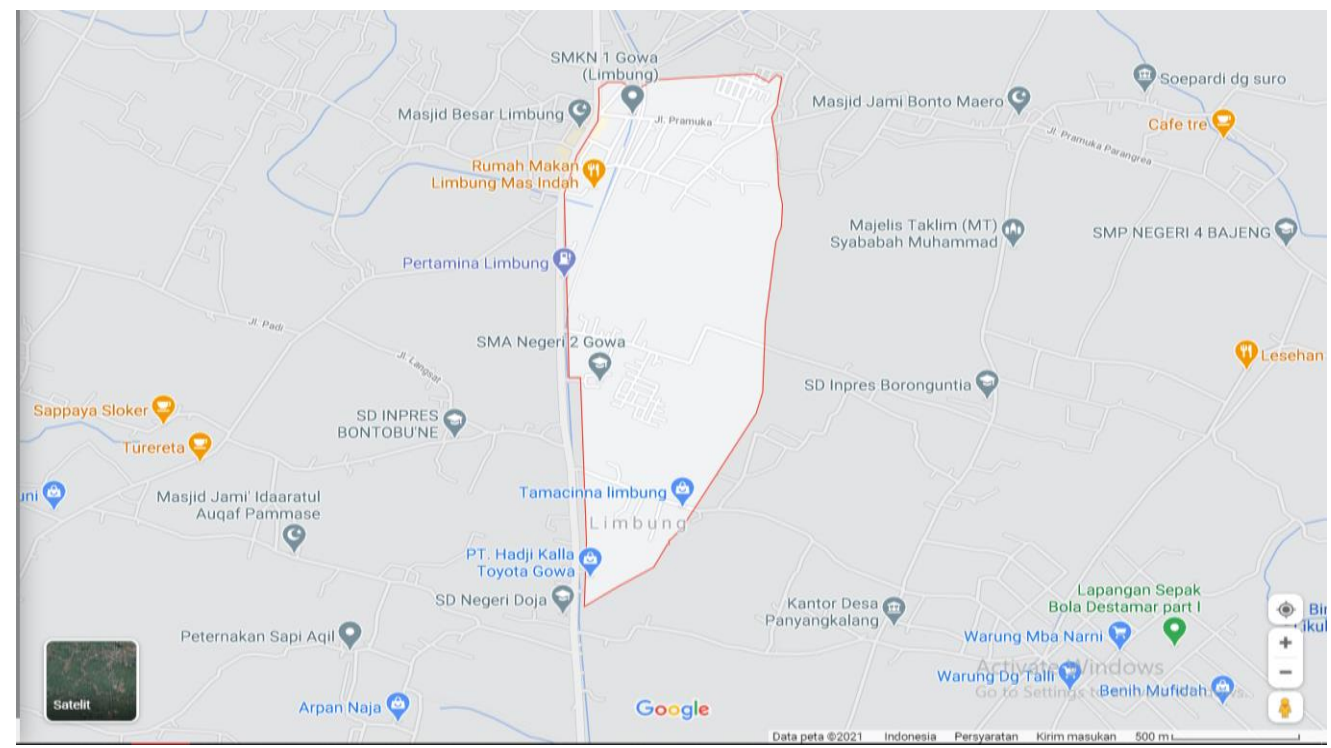

Gambar 1. Peta lokasi pengabdian kepada masyarakat di Dusu Kalebajeng Kec. Bajeng Kab. Gowa

\section{METODE}

1.1 Tahapan Persiapan

Permohonan surat konfirmasi mitra pengabdian dan berkoordinasi dengan kepala dusun tentang rencana kegiatan yang akan dilakukan. Persiapan alat dan instrumen pelatihan. Membagikan kuesioner kepada masyarakat yang berisi tentang identitas. Mempersiapkan masyarakat yang akan terlibat pada pelatihan mitigasi bencana. Mempersiapkan materi, manual book dan perlengkapan yang akan dipakai selama proses pelatihan.

1.2 Tahap Pelaksanaan

Pre test, yang diberikan melalui kuesioner untuk menilai pengetahuan penanganan covid19 kemudian melaksanakan penyuluhan mitigasi bencana covid-19 yang dilakukan melalui metode ceramah, tanya jawab, dan diskusi dengan menggunakan layar LCD dan membagikan leafleat pada masyarakat yang dilibatkan dan terakhir membagikan Post test yang diberikan melalui kuesioner untuk menilai pengetahuan terkait mitigasi bencana Covid-19. 


\subsection{Evaluasi}

1.3.1 Pre test Diberikan sebelum penyuluhan dimulai. Penilaian kegiatan ini dilaksanakan berdasarkan nilai yang dicapai oleh peserta sebelum penyuluhan dimulai. Komponen yang akan dinilai dari pre test adalah pengetahuan dasar mengenai mitigasi bencana covid-19.

1.3.2 Post test

Diberikan setelah penyuluhan berakhir. Penilaian kegiatan ini dilaksanakan berdasarkan nilai yang dicapai oleh peserta setelah penyuluhan berakhir. Komponen yang akan dinilai dari pretest adalah pengetahuan dasar mengenai mitigasi bencana covid-19.

1.3.3 Evaluasi Pelatihan Mitigasi bencana covid-19. Evaluasi pelatihan mitigasi dilakukan oleh tim enumerator dengan cara menilai perhatian masyarakat yang mengikuti pelatihan menggunakan lembar observasi.

1.4 Proses

Kegiatan Pelatihan Mitigasi Bencana Covid-19.

Pelaksanaan kegiatan pukul 09.00-12.00 WITA. Sesuai dengan jadwal yang telah direncanakan.

1.5 Hasil

Terdapatnya peningkatan pengetahuan masyarakat mengenai Tentang Mitigasi Bencana Covid-19 di Dusun Kalebajeng Desa Kalebajeng Kecamatan Bajeng Kabupaten Gowa.

Berikut foto kegiatan pengabdian masyarakat

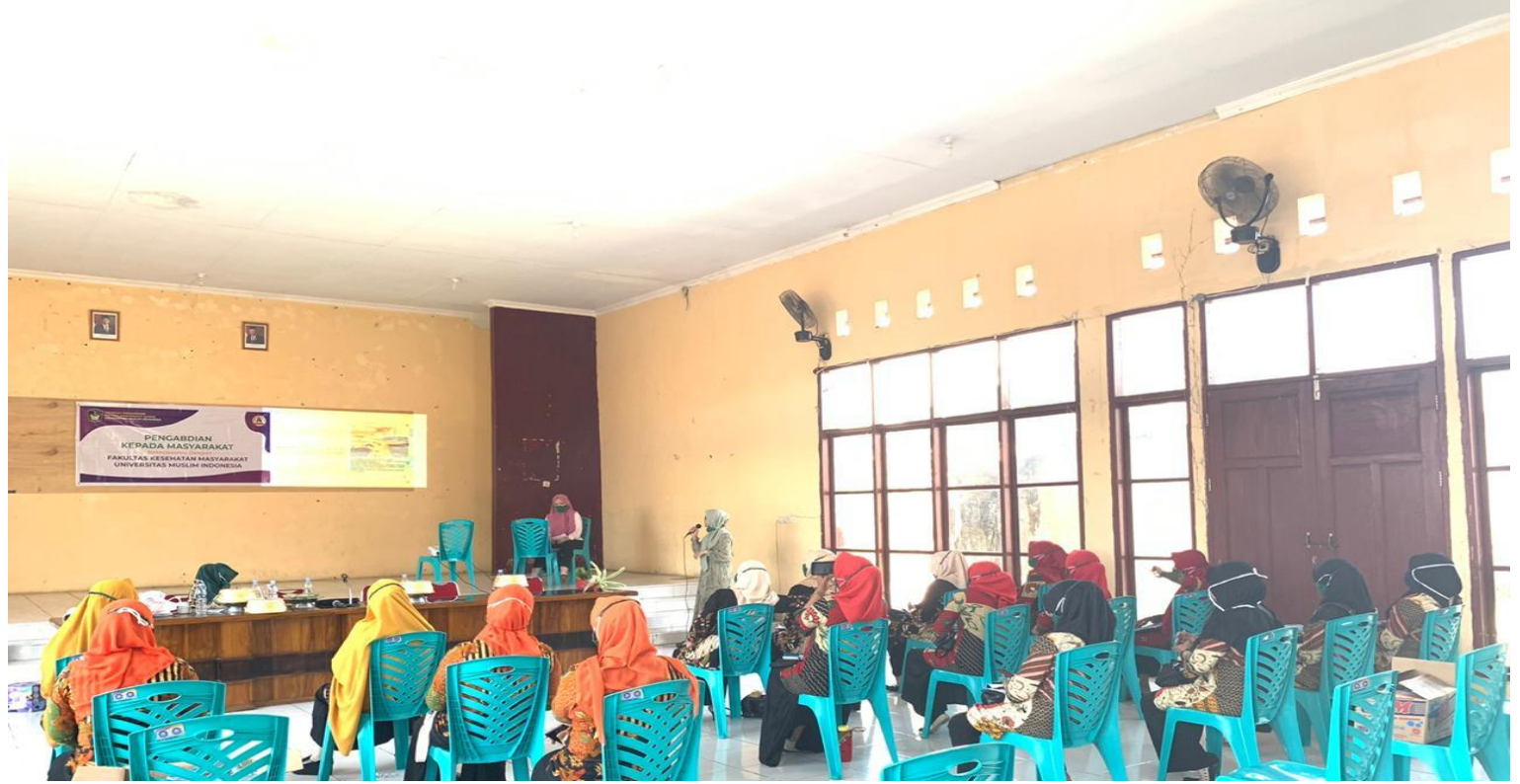

Gambar 2. Penyuluhan materi mitigasi bencana covid-19 di Dusun Kalebajeng

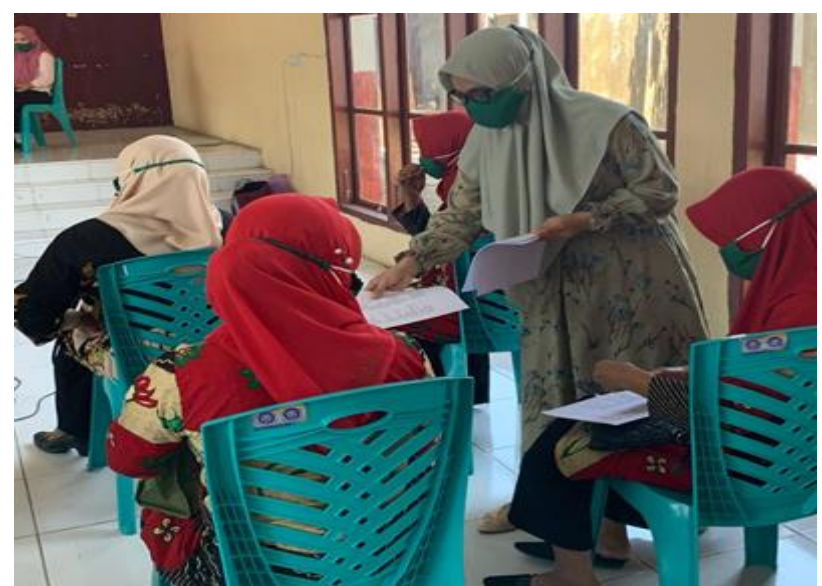

Gambar 3. Pembagian Pretest pada peserta Pelatihan 


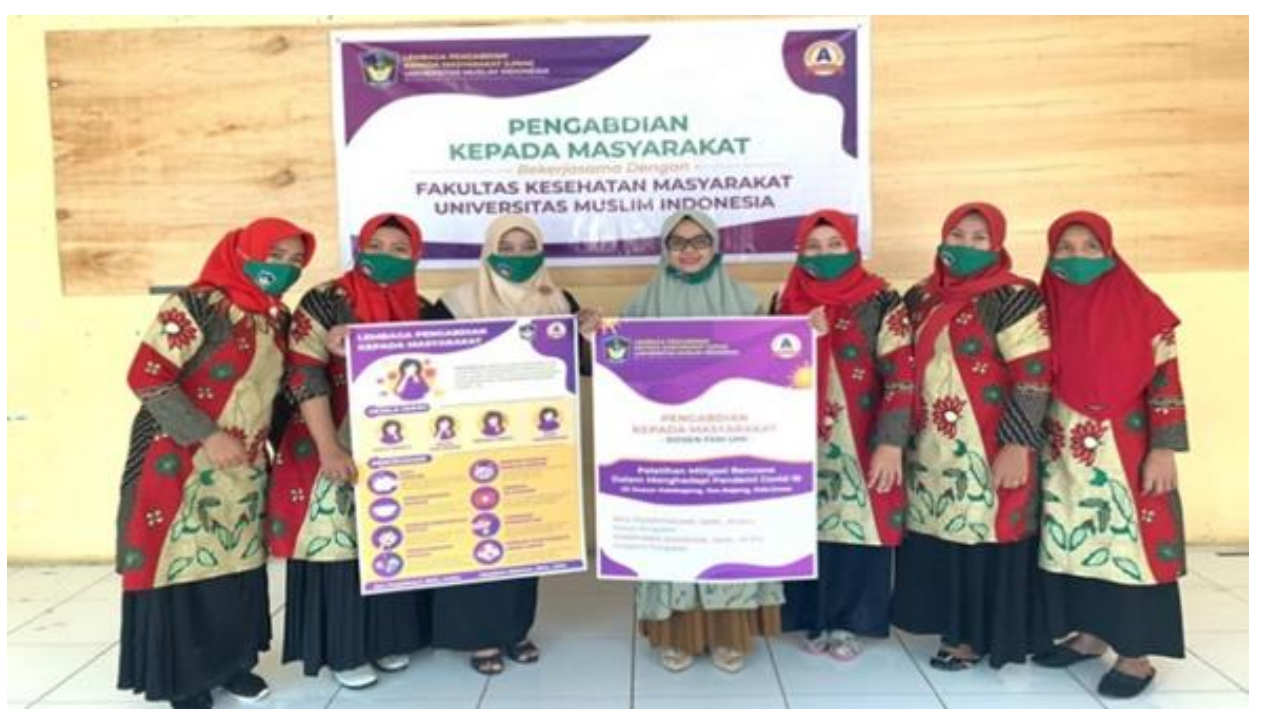

Gambar 4. Foto bersama dengan peserta pelatihan mitigasi bencana covid-19

\section{HASIL DAN PEMBAHASAN}

Dari hasil pengabdian masyarakat yang telah dilakukan oleh tim pengabdi, telah dilaksanakan pelatihan mitigasi bencana covid-19 di Dusun Kalebajeng Desa Kalebajeng Kecamatan Bajeng Kabupaten Gowa. Berdasarkan hasil pre dan post test pada 52 orang yang terdiri dari 10 pertanyaan kuesioner, terdapat peningkatan pengetahuan mengenai mitgasi bencana covid-19. Hasil tersebut dapat diketahui berdasarkan tabel berikut:

Tabel 1

Hasil Pre dan Post Test Pelaksanaan Pengabdian Masyarakat Tentang Mitigasi Bencana Covid-19 di Dusun Kalebajeng Keluarahan Kalebajeng Kecamatan Bajeng Kabupaten Gowa.

\begin{tabular}{|l|c|c|c|c|c|c|}
\hline \multirow{2}{*}{ Kuesioner } & \multicolumn{2}{|c|}{ Salah } & \multicolumn{2}{c|}{ Benar } & \multicolumn{2}{c|}{ Total } \\
\cline { 2 - 7 } & $\mathrm{n}$ & $\%$ & $\mathrm{n}$ & $\%$ & $\mathrm{n}$ & $\%$ \\
\hline Pre Test & 231 & 44.4 & 289 & 55.6 & 520 & 100 \\
\hline Post Test & 97 & 18.7 & 423 & 81.3 & 520 & 100 \\
\hline
\end{tabular}

Sumber: Data Primer

\section{SIMPULAN}

Dari kegiatan pengabdian kepada masyarakat di Dusun Kalebajeng Kelurahan Kalebajeng Kecamatan Bajeng Kabupaten Gowa terdapat peningkatan pengetahuan masyarakat mengenai Mitigasi Bencana Covid-19.

\section{SARAN}

Pentingnya sosialisasi dari pemerintah secara berkelanjutan mengenai mitigasi bencana covid-19 selama masa pandemi berlangsung.

\section{UCAPAN TERIMA KASIH}

Tim pengabdi ingin mengucapkan terimakasih kepada Universitas Muslim Indonesia yang telah memberikan dukungan baik moril maupun materil sehingga kegiatan pengabdian kepada masyarakat ini dapat terwujud, Bapak Camat Kecamatan Bajeng Kabupaten Gowa beserta staf yang telah bersedia menerima tim pengabdi untuk dapat melaksanakan pengabdian 
kepada masyarakat di wilayah kerjanya serta memberikan dukungan penuh terhadap kegiatan ini, dan Seluruh pihak yang terlibat dalam pelaksanaan kegiatan pengabdian ini yang tidak bisa disebutkan satu persatu.

\section{DAFTAR PUSTAKA}

Central Board of Secondary Education. (2006). Natural Hazard dan Disaster Management. Delhi: The Secretary Central Board of Secondary Education.

Etri, Y., Nova, F., Harmawati. (2020). Mencegah Penularan Virus Corona. Jurnal Abdimas Saintika, 2 (1), 33-39.

Undang-Undang Nomor 24 tahun 2007 Tentang Penanggulangan Bencana.

Worldmeters. (March, 2020). Covid-19 Coronavirus Pandemic. Diunduh dari https://www.worldometers.info/coronavirus/ tanggal 10 Maret 2020. 